Article

\title{
Antioxidant and Antimutagenic Activities of Different Fractions from the Leaves of Rhododendron arboreum Sm. and Their GC-MS Profiling
}

\author{
Vandana Gautam ${ }^{1}$, Sukhmeen Kaur Kohli ${ }^{1}$, Saroj Arora ${ }^{1}$, Renu Bhardwaj ${ }^{1, *}$, Mohsin Kazi ${ }^{2}$, \\ Ajaz Ahmad ${ }^{3}$, Mohammad Raish ${ }^{2}$, Majid Ahmad Ganaie ${ }^{4}$ and Parvaiz Ahmad ${ }^{5,6, *}$ \\ 1 Department of Botanical and Environmental Sciences, Guru Nanak Dev University, Amritsar 143005, Punjab, \\ India; vndu.gndu@gmail.com (V.G.); sukhmeenkohli@gmail.com (S.K.K.);sarojarora@gmail.com (S.A.) \\ 2 Department of Pharmaceutics, College of Pharmacy, King Saud University, Riyadh 11451, Saudi Arabia; \\ mkazi@ksu.edu.sa (M.K.); mraish@ksu.edu.sa (M.R.) \\ 3 Department of Clinical Pharmacy, College of Pharmacy, King Saud University, Riyadh 11451, Saudi Arabia; \\ aajaz@ksu.edu.sa \\ 4 Department of Pharmacology, College of Pharmacy, Prince Sattam bin Abdulaziz University, \\ Alkharaj 11942, Saudi Arabia; majidsays@gmail.com \\ 5 Department of Botany and Microbiology, Faculty of Science, King Saud University, Riyadh 11451, Saudi Arabia \\ 6 Department of Botany, S.P. College, Srinagar 190001, Jammu and Kashmir, India \\ * Correspondence: renubhardwaj82@gmail.com (R.B.); parvaizbot@yahoo.com (P.A.); \\ Tel.: +91-987-621-4176 (R.B.); +91-985-837-6669 (P.A.)
}

Received: 28 June 2018; Accepted: 17 August 2018; Published: 3 September 2018

check for updates

\begin{abstract}
In this era of urbanization and environmental pollution, antioxidants and antimutagens derived from plants are promising safeguards for human health. In the current investigation, we analyzed the antioxidant and antimutagenic effects of the hexane, chloroform, and ethyl acetate fractions of Rhododendron arboreum $\mathrm{Sm}$. leaves and determined their chemical composition. The different fractions inhibited lipid peroxidation, repressed the production of nitric oxide radicals, and prevented deoxyribose degradation. The antimutagenic activity of the leaf fractions was analyzed against 4-nitro-O-phenylenediamine, sodium azide and 2-aminofluorene mutagens in two test strains (TA-98 and TA-100) of Salmonella typhimurium. The experiment was conducted using pre- and co-incubation modes. The best results were obtained in the pre-incubation mode, and against indirect acting mutagen. The presence of a number of bioactive constituents was confirmed in the different fractions by GC-MS analysis. The study reveals the strong antioxidant and antimutagenic activity of $R$. arboreum leaves. We propose that those activities of $R$. arboreum might correspond to the combined effect of the phytochemicals identified by GC-MS analysis. To the best of our knowledge, this is the first report on the antimutagenic activity of $R$. arboreum leaves.
\end{abstract}

Keywords: antimutagenic activity; Ames assay; GC-MS; Rhododendron arboreum Sm.; chemical composition; antioxidant activity

\section{Introduction}

In living systems, free radicals and other oxygen-derived species are produced constantly through the mitochondrial respiratory chain and other biological processes [1]. The oxygen-derived moieties include hydroxyl free radicals, singlet oxygen, lipid hydroperoxides, nitric oxide and other reactive oxygen species. All these species are partially reduced forms of atmospheric oxygen $\left(\mathrm{O}_{2}\right)$. Under normal conditions, a balance is maintained between the production and scavenging of reactive 
oxygen species (ROS). An imbalance between the two results in an oxidative burst, which leads to oxidative stress [2]. The major causative agents of oxidative stress are pollutants, chemicals, radiations, toxins, physical stress, and spicy food. The over production of ROS results in increased lipid peroxidation in cell wall, causes damage to DNA, RNA, proteins and alters the calcium and sulfhydryl homeostasis [3]. Other consequences of ROS include an increase in cell proliferation and cell death, pathological neuron deterioration leading to Alzheimer's disease, oxidation of low-density lipoprotein (LDL) resulting in atherosclerosis, gastritis, cancer, central nervous system injury, cardiovascular diseases, diabetes, ageing, and neurodegenerative diseases [4-6].

Antioxidants protect us from various diseases caused by oxidative stress including the DNA mutations [7]. They are also used as food supplements, flavor enhancers, and preservatives for increasing the shelf life of food. However, synthetic antioxidants have several harmful side effects; there is, therefore, a need to identify, isolate, characterize, and utilize natural herbal sources of antioxidants and antimutagens [8]. Plants are rich in secondary metabolites with antioxidant and antimutagenic potential.

Rhododendron arboreum $\mathrm{Sm}$. is an evergreen tree belonging to the Ericaceae family. The young leaves of R. arboreum are said to be poisonous if consumed in large quantities [9]. It is not listed among potential harmful plants on the Horticultural Trades Association list [10]; therefore, the possibility of human poisoning is extremely low. $R$. arboreum is used in traditional medicinal systems but there are not many scientific reports to confirm its medicinal properties. Keeping this in mind, the present study has been undertaken to investigate the chemical composition of chloroform, hexane, and ethyl acetate fractions of Rhododendron arboreum Sm. leaves and to investigate their antioxidant potential in reference to lipid peroxidation, nitric oxide scavenging, and deoxyribose degradation. We also determined the antimutagenic activity of these fractions. We compared its efficacy with that of recognized mutagenic chemicals by using AMES assay to decipher the scientific basis behind its traditional use. This is the first report on the antimutagenic potential of this plant.

\section{Results}

The present study investigated the antioxidant and antimutagenic potential as well as the bioactive phytoconstituents of hexane, chloroform, and ethyl acetate fractions of $R$. arboreum leaves. The following results were observed:

\subsection{Antioxidant Activity}

\subsubsection{Nitric Oxide Quenching Assay}

In the nitric oxide quenching assay, an increase in percentage quenching was noted with the rise in concentration (Figure 1A). The chloroform fraction showed the maximum fold-increase (5.894) with the minimum $\mathrm{IC}_{50}$ value $(150.133 \mu \mathrm{g} / \mathrm{mL})$ compared to those of hexane (fold increase $=5.581$, $\mathrm{IC}_{50}=170.226 \mu \mathrm{g} / \mathrm{mL}$ ) and ethyl acetate (fold-increase $=5.372, \mathrm{IC}_{50}=267.067 \mu \mathrm{g} / \mathrm{mL}$ ) fractions (Table 1 and Figure 2).

\subsubsection{Lipid Peroxidation Assay}

In the lipid peroxidation assay, all the fractions showed an increase in the percentage inhibition in a dose dependent manner (Figure 1B). The chloroform fraction showed the maximum fold-increase (8.98) with an $\mathrm{IC}_{50}$ value of $155.73 \mu \mathrm{g} / \mathrm{mL}$. The hexane fraction showed a fold-increase of 8.97 with an $\mathrm{IC}_{50}$ value of $167.57 \mu \mathrm{g} / \mathrm{mL}$. However, the ethyl acetate fraction showed the minimum fold-increase of 5.02 but the $\mathrm{IC}_{50}$ value of ethyl acetate fraction was minimum $(116.02 \mu \mathrm{g} / \mathrm{mL})$ compared to those of the chloroform and hexane fractions (Table 1 and Figure 2). 


\subsubsection{Site-Specific Deoxyribose Deprivation Assay}

The inhibitory activity of all the fractions against site-specific deprivation of deoxyribose increased with the increase in concentration (Figure 1C). The chloroform fraction showed the maximum fold-increase (11.163) in the site-specific deoxyribose deprivation assay but it had the maximum $\mathrm{IC}_{50}$ value $(698.372 \mu \mathrm{g} / \mathrm{mL})$ compared to those of the hexane (fold-increase $=4.959, \mathrm{IC}_{50}=181.585 \mu \mathrm{g} / \mathrm{mL}$ ) and ethyl acetate (fold-increase $=9.84, \mathrm{IC}_{50}=191.907 \mu \mathrm{g} / \mathrm{mL}$ ) fractions (Table 1 and Figure 2).

\subsubsection{Non-Site Specific Deoxyribose Deprivation Assay}

All the fractions showed significant inhibition in the non-site-specific deoxyribose deprivation assay and the activity increased with the increase in the concentration (Figure 1D). The ethyl acetate fraction demonstrated the maximum protective activity (fold-increase $=1.85$ ) and minimum $\mathrm{IC}_{50}$ value $(96.817 \mu \mathrm{g} / \mathrm{mL})$. The chloroform fraction showed a fold-increase of 4.726 and an $\mathrm{IC}_{50}$ value of $118.353 \mu \mathrm{g} / \mathrm{mL}$. Hexane fraction caused a fold-increase of 3.026 and the $\mathrm{IC}_{50}$ was $226.412 \mu \mathrm{g} / \mathrm{mL}$ (Table 1 and Figure 2).
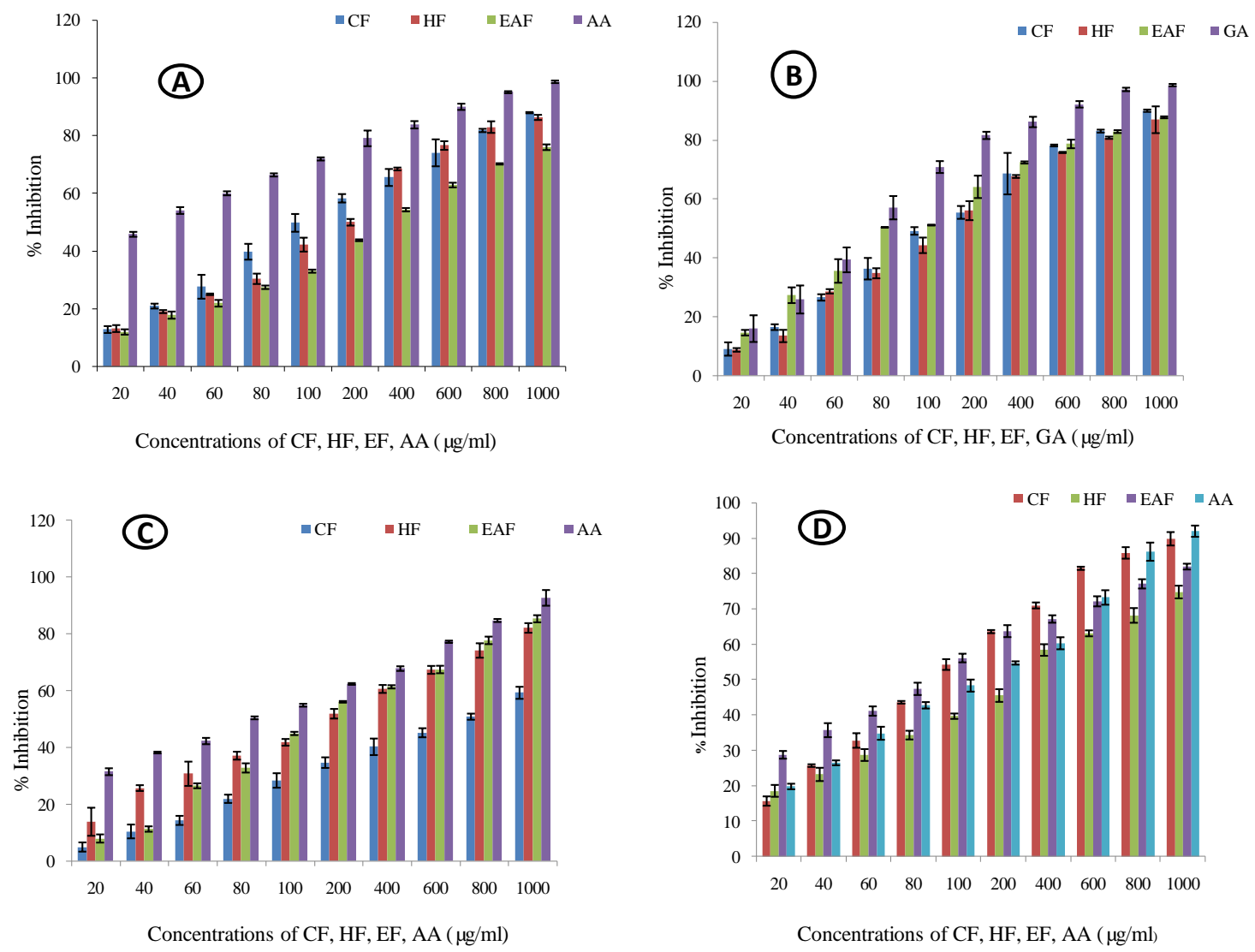

Figure 1. Antioxidant activity of Rhododendron arboreum fractions: (A) Nitric oxide scavenging assay; (B) Lipid peroxidation assay; (C) Site specific deoxyribose deprivation assay and; (D) Non- site specific deoxyribose deprivation assay. (CF- chloroform fraction; HF- hexane fraction; EAF- ethyl acetate fraction; AA- ascorbic acid; GA- gallic acid). 
the per-plate concentration of the Rhododendron fractions. The fractions significantly reduced the number of induced histidine revertant colonies in the pre-incubation mode whereas, comparatively, lower efficiency of reducing the mutagenicity was observed in the co-incubation mode in all the fractions. Moreover, better results were obtained against the S9 dependent mutagen (2-aminofluorene) through the metabolic activation than against the direct mutagens (NPD and sodium azide) without metabolic activation in both the tester strains.
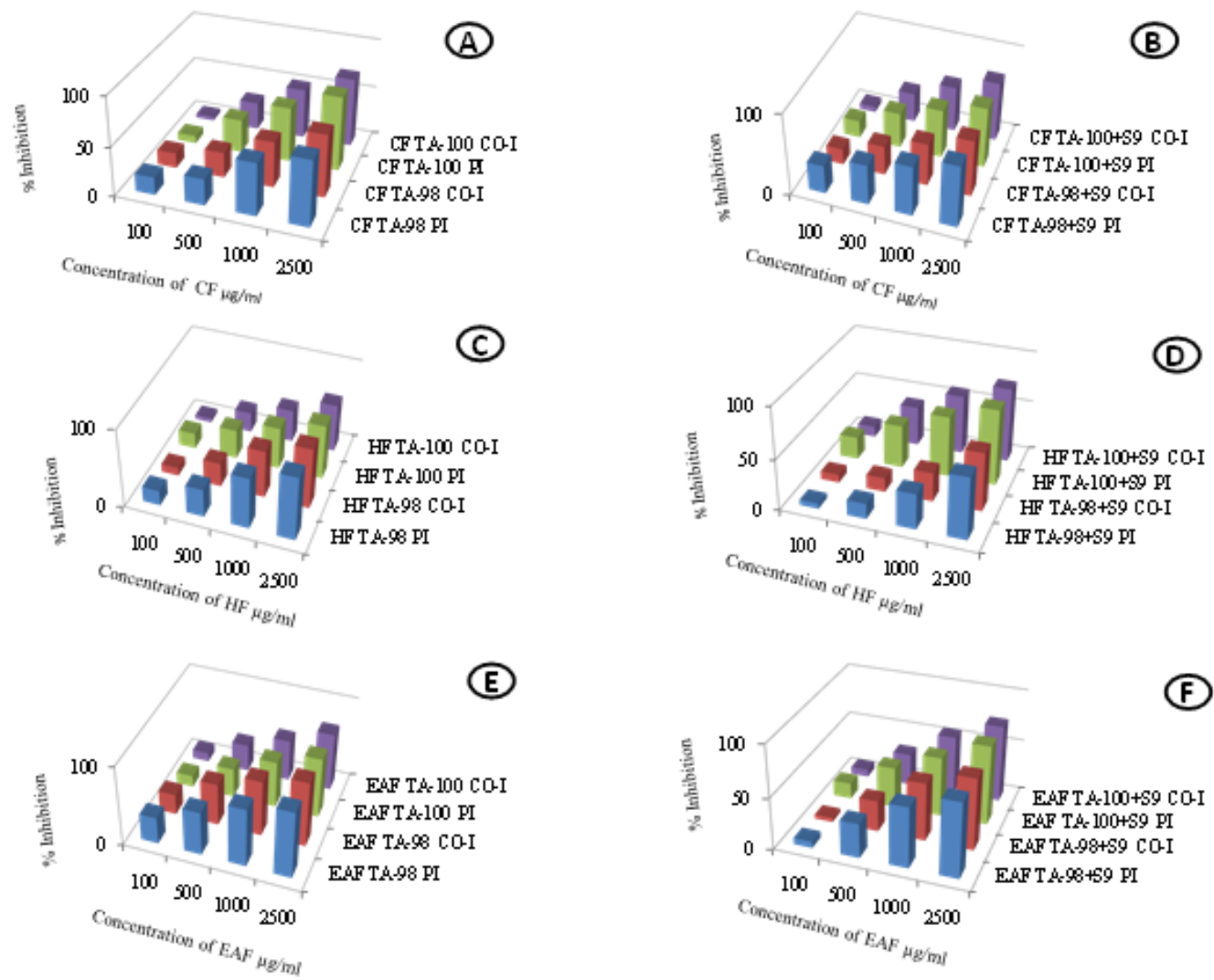

Figure 3. Antimutagenic activity of Rhododendron arboreum fractions in TA-98 and TA-100 strains of Salmonella typhimurium. Pre-incubation (PI) and co-incubation (Co-I) modes of experimentation; without metabolic activation against direct acting mutagens, 4-nitro- $O$-phenylenediamine for TA-98 \& sodium azide for TA-100 and with metabolic activation against 2-aminofluorene using rat liver homogenate (S9). (A) Chloroform fraction (CF) without metabolic activation; (B) Chloroform fraction (CF) with metabolic activation; (C) Hexane fraction (HF) without metabolic activation; (D) Hexane fraction (HF) with metabolic activation; (E) Ethyl acetate fraction (EAF) without metabolic activation; (F) Ethyl acetate fraction (EAF) with metabolic activation.

In the chloroform fraction, maximum activity of $75.679 \%$ was observed in the TA-100 strain against the directly acting mutagen in the pre-incubation mode (Figure 3A.) whereas in the case of S9 dependent mutagen, maximum activity of $75.741 \%$ was observed with TA-98 strain in the pre-incubation mode (Figure 3B). In the hexane fraction, maximum activity of $81 \%$ was observed in the TA-98 strain in the pre-incubation mode against the directly acting mutagen (Figure 3C) whereas, maximum activity of $75.012 \%$ was observed with the TA-100 strain in the pre-incubation mode against the S9 dependent mutagen (Figure 3D). The activity of the ethyl acetate fraction against the directly acting mutagen was maximum $(83.48 \%$ ) for the TA-98 strain in the pre-incubation mode (Figure 3E) whereas against the indirectly acting mutagen, maximum activity of $76.869 \%$ was observed with the TA-100 strain in the pre-incubation mode (Figure 3F). The honestly significant difference (HSD) values 
and the F ratio for treatment, dose and, interaction between the treatment and dose obtained from the two-way analysis of variance are given in Table 2.

Table 2. The honestly significant difference (HSD) values and F ratio for treatment, dose and, interaction between treatment and dose obtained from 2-way analysis of variance.

\begin{tabular}{|c|c|c|c|c|c|}
\hline & \multirow{2}{*}{$\begin{array}{l}\text { Degree of } \\
\text { Freedom }\end{array}$} & \multicolumn{4}{|c|}{ F-Ratio } \\
\hline & & (TA-98) & (TA-98+S9) & (TA-100) & (TA-100+S9) \\
\hline \multicolumn{6}{|c|}{ Chloroform Fraction } \\
\hline F ratio Treatment & 1,40 & $23.19^{* * *}$ & $482.9^{* * *}$ & $97.69^{* * *}$ & $160.8^{* * *}$ \\
\hline F ratio Dose & 3,40 & $1017^{* * *}$ & $1384^{* * *}$ & $3484^{* * *}$ & $2267^{* * *}$ \\
\hline F ratio Treatment $\times$ Dose & 3,40 & $3.171 * *$ & $13.14^{* * *}$ & 0.748 & $25.08^{* * *}$ \\
\hline HSD & & 154.2 & 131.8 & 115.7 & 116.2 \\
\hline \multicolumn{6}{|c|}{ Hexane Fraction } \\
\hline F ratio Treatment & 1,40 & $24.84^{* * *}$ & 2.475 & $373.4^{* * *}$ & $88.68^{* * *}$ \\
\hline F ratio Dose & 3,40 & $611.1^{* * *}$ & $398.5 * * *$ & $1367 * * *$ & $707.1 * * *$ \\
\hline F ratio Treatment $\times$ Dose & 3,40 & 0.67 & $2.606^{*}$ & $3.294^{* *}$ & $18.11^{* * *}$ \\
\hline HSD & & 297.4 & 159 & 142.2 & 187.3 \\
\hline \multicolumn{6}{|c|}{ Ethyl Acetate Fraction } \\
\hline F ratio Treatment & 1,40 & $42.24^{* * *}$ & $2.399 *$ & $37.12 * * *$ & $22.94^{* * *}$ \\
\hline F ratio Dose & 3,40 & $1407^{* * *}$ & $319.1^{* * *}$ & $1607^{* * *}$ & $791^{* * *}$ \\
\hline F ratio Treatment $\times$ Dose & 3,40 & $4.286^{* *}$ & 0.018 & 1.502 & $3.663 * *$ \\
\hline HSD & & 153.2 & 370.1 & 164.5 & 240.4 \\
\hline
\end{tabular}

* significant at $p \leq 0.100 ;{ }^{* *}$ significant at $p \leq 0.05 ;{ }^{* * *}$ significant at $p \leq 0.001$ level of significance.

\subsection{Analysis Using GC-MS}

The GC-MS study reveals that in the $R$. arboreum leaves, the chloroform fraction contained 24 compounds, the hexane fraction contained 17 compounds, and the ethyl acetate fraction contained 26 compounds (Table 3). Of these, 3,7,11,15-tetramethyl-2-hexadecen-1-ol, linoleic acid, 9-octadecenoic acid, 3,10-epoxy-(3 $\beta, 10 \beta)$-D:B-friedo-18,19-secolup-19-ene, methyl commate C, andmethyl commate $\mathrm{D}$ were present in all the three fractions. 2-Hexyl-1-decanol, Octadecyl Chloroacetate, 3-bromo-3 $\beta$-cholest-5-ene, methyl commate B andolean-12-en-28-al were present in the chloroform and hexane fractions. 1-Tetradecene, neophytadiene, 3(E)-eicosene and $9(E)$-eicosene were present in the chloroform and ethyl acetate fractions. 2,6,10,15,19,23-Hexamethyl- 2,6,10,14,18,22-tetracosahexaene, and vitamin E were present in the ethyl acetate and hexane fractions (Table 3). The existence of these constituents in the leaves of $R$. arboreum confirms its potential for use in the therapeutics.

Table 3. Phytochemicals present in chloroform, hexane and ethyl acetate fractions of Rhododendron arboreum leaves.

\begin{tabular}{cccc}
\hline No. & Chloroform Fraction & Hexane Fraction & Ethyl Acetate Fraction \\
\hline 1 & 1-Dodecene & 3,7,11,15-Tetramethyl-2-hexa-decen-1-ol & 1-Dodecene \\
2 & 1-Tetradecene & 14-Methylpentadecanoic acid, & 1-Tetradecene \\
3 & Docosanoic acid & methyl ester & 9-Octadecenoic acid \\
4 & 1-Nonadecene & 3,7,11,15-tetramethyl-2 & 2,4-DI-Tert-butylphenol, \\
5 & Neophytadiene & -hexadecen-1-ol, & 9-(E)-Eicosene, \\
6 & 3,7,11,15-Tetramethyl-2 & Linoleic acid & 9-Octadecenoic acid \\
\hline
\end{tabular}


Table 3. Cont.

\begin{tabular}{|c|c|c|c|}
\hline 7 & Pentadecanoic acid & $\begin{array}{c}\text { 1,2-Benzenedicarboxylic acid, } \\
\text { ditridecyl ester }\end{array}$ & 3-(E)-Eicosene \\
\hline 8 & 3-(E)-Eicosene, & 2-Hexyl-1-decanol & Neophytadiene \\
\hline 9 & $\begin{array}{l}\text { 3,7,11,15-Tetramethyl-, } \\
\text { 2-hexadecen-1-ol, } \\
{\left[R-\left[R^{*}, R^{*}-(E)\right]\right] \text { phytol }}\end{array}$ & $\begin{array}{l}\text { 2,6,10,14,18,22- } \\
\text { Tetracosa-hexaene }\end{array}$ & $\begin{array}{c}\text { 3,7,11,15-Tetramethyl-2 } \\
\text {-hexadecen-1-ol }\end{array}$ \\
\hline 10 & Linoleic acid & Octadecyl Chloroacetate & 2-Methyl-7-octadecyne \\
\hline 11 & 9-Octadecenoic acid & Vitamin E & Butyl-2-methylpropylphthalate \\
\hline 12 & 9-(E)-Eicosene & $\begin{array}{l}\text { 3,10-Epoxy-D:B-friedo- } \\
\text { 18,19-secolup-19-ene }\end{array}$ & Pentadecanoic acid \\
\hline 13 & Heptadecyl trifluoroacetate & 3-Bromo-(3ß)-cholest-5-ene & Pentadecyl trifluoroacetate \\
\hline 14 & Hexatriacontane & Methyl commate C & $\begin{array}{l}\text { 3,7,11,15-Tetramethyl- } \\
\text { 2-hexadecen-1-ol }\end{array}$ \\
\hline 15 & 2-Hexyl-1-decanol, & Methyl commate B & Linoleic acid \\
\hline 16 & $\begin{array}{l}\text { Docosyl } \\
\text { pentafluoropropionate }\end{array}$ & Methyl commate D & Eicosanoic acid \\
\hline 17 & Farnesol isomer a & Olean-12-en-28-al & 9-Tricosene \\
\hline 18 & Octadecyl Chloroacetate & & 1-Docosanol behenic alcohol \\
\hline 19 & $\begin{array}{l}\text { 3,10-Epoxy-D:B-friedo- } \\
\text { 18,19-secolup-19-ene }\end{array}$ & & 1,2-Benzenedicarboxylic acid, \\
\hline 20 & Cholest-5-ene & & $\begin{array}{c}\text { Nonadecyl } \\
\text { pentafluoropropionate }\end{array}$ \\
\hline 21 & Methyl commate C & & Vitamin E \\
\hline 22 & Methyl commate B & & $\begin{array}{l}\text { 3,10-Epoxy-( } 3 \beta, 10 \beta)-\mathrm{D}: \mathrm{B}- \\
\text { friedo-18,19-secolup-19-ene }\end{array}$ \\
\hline 23 & Methyl commate D & & $3 \beta$-Stigmast-5-en-3-ol \\
\hline 24 & Olean-12-en-28-al & & Methyl commate C \\
\hline 25 & & & Methyl commate D \\
\hline 26 & & & Urs-12-en-28-ol \\
\hline
\end{tabular}

\section{Discussion}

All the fractions of Rhododendron arboreum leaves showed promising effect in all the antioxidant assays. The results established that the radical quenching effects of the different fractions were dose dependent (Figure 1) The Pearson's correlation coefficient data indicate that the nitric oxide value positively correlated with lipid peroxidation and site and non-site specific deoxyribose deprivation values at $p<0.05$ (Table 4). The lipid peroxidation data positively correlate with the site-specific and non-site-specific deoxyribose deprivation data at $p \leq 0.05$. A significant positive correlation was observed among the site-specific and non-site-specific deoxyribose deprivation values. The results suggest that $R$. arboreum leaves are proficient in protecting against oxidative stress. The possible reason for this could be the fact that the phytoconstituents of $R$. arboreum like vitamin $\mathrm{E}$, 3,7,11,15-tetramethyl-2-hexadecen-1-ol, efficiently scavenge the free radicals [11,12].

Table 4. Pearson's correlation coefficients $(\mathrm{R})$ among antioxidant activity (NO = Nitric oxide scavenging, $\mathrm{LP}=$ Lipid peroxidation, SSDD = Site specific deoxyribose deprivation, NSSDD = Non-site specific deoxyribose deprivation).

\begin{tabular}{ccccc}
\hline & NO & LP & SSDD & NSSDD \\
\hline NO & 1 & & & \\
LP & $0.9979 *$ & 1 & 1 & \\
SSDDA & $0.9971^{*}$ & $0.9946^{*}$ & $0.9980^{*}$ & $0.9923 *$ \\
NSSDDA & $0.9983^{*}$ & 0.01. & 1 \\
\hline \multicolumn{5}{r}{ * Correlations significant at $p \leq 0.0$}
\end{tabular}


The results also indicate that the leaf fractions have the potential to protect the DNA of the tester strains from frame shift or base pair mutations. The analysis of variance showed significant differences between the TA-100 and TA-98 strains (Table 2). The possible mechanism of action for this could be that some secondary metabolites like vitamin E $[13,14]$ might act as direct anti-mutagens by reverting the toxic effect of mutagens or by inactivating them or they might hinder the direct contact of mutagens with the cells by making changes in their absorption rates. This could be achieved either by reacting with the mutagens and making nontoxic byproducts or by binding at the site of action of the mutagens, thereby, not allowing the mutagen to come in direct contact with the cell. It is evident from the results that the pre-incubation mode of experiment is more efficient in protecting the cells from mutation. This proves that during the incubation period, the phytoconstituents of the $R$. arboreum leaf extracts might react with the mutagen to make it less toxic or nontoxic. The antimutagenicity of several plant extracts has been reported against several mutagens, such as sodium azide, 2-aminofluorene, 2-nitrofluoranthene, and heterocyclic amines [15-18]. However, to the best of our knowledge, this is the first report regarding the antimutagenic activity of $R$. arboreum leaf fractions against sodium azide, 4-nitro-O-phenylenediamine, and 2-aminofluorene in the two tester strains (TA-98 and TA-100) of S. typhimurium. To find out the causative agents responsible for these antioxidant and antimutagenic activities, the phytoconstituents of the fractions were identified using the GC-MS technique. We could identify 24 compounds in the chloroform fraction, 17 in the hexane fraction, and 26 in the ethyl acetate fraction. These compounds are reported to possess different activities. For example, 9-octadecenoic acid has antimicrobial and antibacterial potential [19]. A literature review shows that vitamin E exhibits curative potential against leukemia, tumors, cancer, dermatitis, ulcers and inflammation along with antiaging, analgesic, antidiabetic, vasodilatory, antispasmodic, antibronchitic, antiplasmodial, antimicrobial, and anti-inflammatory properties [20,21]. 1,2-Benzenedicarboxylic acid has antimicrobial properties [14]. 9,12-Octadecadien-1-ol possesses anti- arthritic and anti-inflammatory properties [21]. Octadecene is reported to exhibit anticancer, antioxidant, and antimicrobial activities [22,23]. Candida albicans uses farnesol as a sensing molecule to stop filamentation [24]. (3 $\beta$ )-Stigmast-5-en-3-ol helps in cholesterol lowering [25] and curing proliferation [26]. (3 $\beta$ )-Stigmast-5-en-3-ol is also used as anti-diabetic agent that controls glucose transport. It restores the uptake of glucose without the stimulus of insulin, therefore, indicating insulin-like property [27]. The presence of steroids, terpenoids, flavonoids, anthraquinones, tannins, phlobatannins in leaves of $R$. arboreum have been reported [28]. In Rhododendron arboreum Sm. ssp. nilagiricum (Zenker) Tagg. leaves, phenols, flavonoids, quinones, steroids, tannins, xanthoproteins and coumarins are reported [29]. The presence of these compounds in the leaves of $R$. arboreum indicates that they are promising candidates for therapeutic use. 9,12-Octadecadienoic acid is helpful in curing inflammation, microbial infection and arthritis [30]. Linoleic acid, heptadecanoic acid, and oleic acid possess antimicrobial activities [31].

\section{Materials and Methods}

\subsection{Sample Preparation}

The leaves were procured from Kataula village in the Kullu district of Himachal Pradesh and were authenticated at the herbarium of Guru Nanak Dev University, Amritsar. The leaves were washed with double distilled water, dried in shade, and ground to a fine powder in a mixer-grinder. The $1 \mathrm{~kg}$ powder was then extracted with $80 \%$ methanol to get $68.38 \mathrm{~g}(6.838 \%)$ crude extract, $50 \mathrm{~g}$ of which was further fractionated using different solvents (polarity wise) to obtain $13.53 \mathrm{~g}(27.06 \%)$ hexane fraction, $15.03 \mathrm{~g}(30.06 \%)$ chloroform fraction and $17.32 \mathrm{~g}(34.64 \%)$ ethyl acetate fraction. The fractions were dried out with the help of rotary vacuum evaporator at a temperature of 30 degree Celsius. For antioxidant assays, $1000 \mu \mathrm{g} / \mathrm{mL}$ stock solutions of different fractions were prepared, which were further used to make different concentrations $(20,40,60,80,100,200,400,600,800,1000 \mu \mathrm{g} / \mathrm{mL}$ ) by 
serial dilution. To assess the antimutagenic activity, 100, 500, 1000 and $2500 \mu \mathrm{g} / \mathrm{mL}$ concentrations of different fractions were prepared.

\subsection{Antioxidant Activity}

\subsubsection{Lipid Peroxidation Assay}

Lipid peroxidation assay was performed using the method described by Halliwell and Gutteridge [32] after slight modifications. The leaf fractions $(1 \mathrm{~mL})$ at different concentrations were mixed with $0.5 \mathrm{~mL} \mathrm{KCl}$ and $0.5 \mathrm{~mL}$ rat liver homogenate. To this mixture, $100 \mu \mathrm{L} \mathrm{FeCl}_{3}$ was added to induce lipid peroxidation. After incubating for $30 \mathrm{~min}$ at $37^{\circ} \mathrm{C}, 2 \mathrm{~mL}$ of ice cold $0.25 \mathrm{~N} \mathrm{HCl}$ with $15 \%$ trichloroacetic acid (TCA) and $0.5 \%$ thiobarbituric acid (TBA) was added to the mixture. Thereafter, $50 \mu \mathrm{L}$ butylated hydroxytoluene (BHT) was added, followed by incubation of $60 \mathrm{~min}$ at $100{ }^{\circ} \mathrm{C}$. After centrifugation of $3 \mathrm{~min}$ at $900 \mathrm{~g}$ optical density was noted at $532 \mathrm{~nm}$. Calculation was done as follows:

$$
\% \text { Inhibition }=\frac{A c-A s}{A c} \times 100
$$

$A c=$ Control absorbance

As $=$ Sample absorbance

\subsubsection{Nitric Oxide Quenching Assay}

The nitric oxide quenching activity was estimated according to the technique given by Marcocci et al. [33], with minor alterations. $1 \mathrm{~mL}$ of each fraction was mixed with $0.5 \mathrm{~mL}$ sodium nitroprusside $(5 \mathrm{mM})$ and incubated at $25^{\circ} \mathrm{C}$ for $30 \mathrm{~min}$. Subsequently, $1.5 \mathrm{~mL}$ Griess reagent was mixed with the above solution and the absorbance was read at $546 \mathrm{~nm}$. The percentage quenching of nitric oxide was estimated as:

$A c=$ Control absorbance

$A s=$ Sample absorbance

\subsubsection{Deoxyribose Deprivation Assay}

Deoxyribose deprivation assay was conducted by the technique given by Halliwell et al. [34] and Arouma et al. [35] after slight modifications. This assay was divided into site and non-site-specific mode. In the site-specific mode, $100 \mu \mathrm{L}$ of phosphate buffer was combined with $20 \mu \mathrm{L}$ of $\mathrm{FeCl}_{3}(10 \mathrm{mM})$, $100 \mu \mathrm{L} \mathrm{H}_{2} \mathrm{O}_{2}(10 \mathrm{mM}), 360 \mu \mathrm{L}$ of $10 \mathrm{mM}$ deoxyribose, $1 \mathrm{~mL}$ of the fraction, $320 \mu \mathrm{L}$ of phosphate buffer, and $100 \mu \mathrm{L}$ of $1 \mathrm{mM}$ of ascorbic acid. In the non-site-specific mode, $100 \mu \mathrm{L}$ EDTA $(1 \mathrm{mM})$ was mixed with $20 \mu \mathrm{L} \mathrm{FeCl}_{3}(10 \mathrm{mM}), 100 \mu \mathrm{L} \mathrm{H}_{2} \mathrm{O}_{2}(10 \mathrm{mM}), 360 \mu \mathrm{L}$ of $10 \mathrm{mM}$ deoxyribose, $1 \mathrm{~mL}$ of the fraction, $320 \mu \mathrm{L}$ of phosphate buffer and $100 \mu \mathrm{L}$ of $1 \mathrm{mM}$ ascorbic acid. After incubating at $37^{\circ} \mathrm{C}$ for $1 \mathrm{~h}, 1 \mathrm{~mL}$ of the above solution was mixed with $1 \mathrm{~mL}$ TCA $(10 \%)$ and $1 \mathrm{~mL}$ TBA $(0.5 \%)$. The mixture was heated for $90 \mathrm{~min}$ on a water bath at $80{ }^{\circ} \mathrm{C}$ until pink color was formed which was read at $532 \mathrm{~nm}$ with spectrophotometer. The calculation was done as follows:

$$
\% \text { Inhibition }=\frac{A c-A s}{A c} \times 100
$$

$A c=$ Control absorbance

As $=$ Sample absorbance

\subsection{Antimutagenic Activity}

The tester strains TA-98 and TA-100 of S. typhimurium were used to examine the antimutagenic potential of the hexane, chloroform, and ethyl acetate fractions of $R$. arboreum leaves. The method 
suggested by Maron and Ames [36] was employed for the assay incorporating slight alterations given by Bala and Grover [37]. For TA-98, 4-nitro-O-phenylenediamine (NPD) and for TA-100, sodium azide $\left(\mathrm{NaN}_{3}\right)$ was used as the direct acting mutagen. The different concentrations of plant fractions $(100,500$, 1000, $2500 \mu \mathrm{g} / 0.1 \mathrm{~mL}$ ) were prepared in dimethyl sulfoxide (DMSO) and were analyzed using pre-incubation and co-incubation modes of the experiment so that the bio-antimutagenicity and desmutagenicity could be differentiated. We used 2-aminofluorene (2-AF) as a promutagen in the presence of liver homogenate of rat (S9 mix) [38]. The liver homogenate activates the promutagen through the cytochrome P450 metabolic activation system. The antimutagenic activity was calculated as:

$$
\% \text { Inhibition }=\frac{X-Y}{X-Z} \times 100
$$

$X=$ number of histidine revertants induced by mutagen alone (+ve control). $Y=$ number of histidine revertants induced by mutagen in the presence of extract/fraction. $Z=$ number of histidine revertants induced by extract/fraction alone ( - ve control).

\subsection{Analysis Using GC-MS}

The hexane, chloroform, and ethyl acetate fractions of $R$. arboreum leaves were analyzed using a GCMS-QP2010 Plus system (Shimadzu, Kyoto, Japan). The instrument conditions and parameters used for analysis were as follows: Column oven temperature: $70{ }^{\circ} \mathrm{C}$ for first $5 \mathrm{~min}$; increased to $250{ }^{\circ} \mathrm{C}$ at a rate of $10^{\circ} \mathrm{C} / \mathrm{min}$ and held for next 10 minutes; further increased to $300^{\circ} \mathrm{C}$ at a rate of $10^{\circ} \mathrm{C} / \mathrm{min}$ and held at this temperature for $10 \mathrm{~min}$. Carrier gas: Helium. Injection temperature: $280^{\circ} \mathrm{C}$. Injection mode: Splitless. Sampling time: $1 \mathrm{~min}$. Pressure: $110.8 \mathrm{kPa}$. Total flow: $38.9 \mathrm{~mL} / \mathrm{min}$. Column flow: $1.71 \mathrm{~mL} / \mathrm{min}$. Linear velocity: $47.9 \mathrm{~cm} / \mathrm{sec}$. Purge flow: $3 \mathrm{~mL} / \mathrm{min}$. All the discovered compounds were recognized by evaluating their mass spectra with those listed in the National Institute of Standard and Technology (NIST08s) and Wiley 7 libraries.

\subsection{Statistical Analysis}

Results are given as mean of three replications \pm standard error. For the interactions at $5 \%$ level of significance, 1-way and 2-way analysis of variance (ANOVA) were performed using MS Excel. Pearson's correlation coefficients were also calculated.

\section{Conclusions}

The results reveal that the different leaf fractions of $R$. arboreum inhibit lipid peroxidation, repress the nitric oxide radicals, and prevent the deprivation of deoxyribose. Rhododendron arboreum leaves also possess considerable antimutagenic activity in against base-pair and frame-shift mutations. These activities can be credited to the synergistic effect of different phytoconstituents of leaves. Based on the results of present study, it is suggested that the selected components of $R$. arboreum leaves may be used as food additives or leaves can serve as raw material for development of medicines.

Supplementary Materials: The following are available online: Supplementary file S-1-Tables: GC-MS tables of Rhododendron arboreum leaf fractions with retention times of different compounds; Supplementary file S-1-Histograms: Histograms for the antimutagenic activity of different fractions of Rhododendron arboreum leaves; Supplementary files S-3: GCMS report Chloroform leaves; Supplementary files S-4: GCMS report Hexane leaves; Supplementary files S-5: GCMS report Ethyl Acetate leaves.

Author Contributions: Conceptualization, R.B. and P.A.; Methodology, V.G. and M.K.; Software, A.A., M.R., M.A.G.; Validation, S.K.K., S.A. and R.B.; Formal Analysis, P.A.; Investigation, V.G.; Data Curation, M.K. and V.G.; Writing-Original Draft Preparation, V.G. and S.K.K.; Writing-Review \& Editing, R.B. and P.A.; Supervision, R.B., P.A.; Project Administration, M.K.; Funding Acquisition, M.K.

Funding: This research was funded by the Deanship of Scientific Research at King Saud University grant number [RG-1435-017] and The APC was funded by [the Deanship of Scientific Research at King Saud University. 
Acknowledgments: The authors would like to extend their sincere appreciation to the Deanship of Scientific Research at King Saud University for its funding this Research group NO (RG-1435-017).

Conflicts of Interest: The authors declare that no conflict of interest exists.

\section{References}

1. Cocheme, H.M.; Murphy, M.P. Mitochondria as a source of reactive oxygen species. J. Biochem. 2009. [CrossRef]

2. Galle, J. Oxidative stress in chronic renal failure. Nephrol. Dial. Transpl. 2001, 16, 2135-2137. [CrossRef]

3. Stohs, S.J.; Bagghi, D. Review: Oxidative mechanisms in the toxicity of metal ions. Free Rad. Biol. Med. 1995, 18, 321-336. [CrossRef]

4. Berlinera, J.A.; Heineckeb, W.J. Review: The role of oxidized lipoproteins in atherogenesis. Free Rad. Biol. Med. 1996, 20, 707-727. [CrossRef]

5. Valko, M.; Leibfritz, D.; Moncola, J.; Cronin, M.T.D.; Mazura, M.; Telser, J. Free radicals and antioxidants in normal physiological functions and human disease. Int. J. Biochem. Cell Biol. 2007, 39, 44-84. [CrossRef] [PubMed]

6. El-Hela, A.; Abdullah, A. Antioxidant and antimicrobial activities of methanol extracts of some Verbena species: In vitro evaluation of antioxidant and antimicrobial activity in relation to polyphenolic content. J. Appl. Sci. Res. 2010, 6, 683-689.

7. Słoczyńska, K.; Powroźnik, B.; Pękala, E.; Waszkielewicz, A.M. Antimutagenic compounds and their possible mechanisms of action. J. Appl. Genet. 2014, 55, 273-285. [CrossRef] [PubMed]

8. Finkel, T. Oxidant signals and oxidative stress. Curr. Opin. Cell Biol. 2003, 15, 247-254. [CrossRef]

9. Srivastava, P. Rhododendron arboreum: An overview. J. Appl. Pharm. Sci. 2012, 2, 158-162.

10. The Retailers Code of Practice for Potentially Harmful Plants; Horticultural Trades Association; Guy's \& St Thomas' Poisons Information Service and Royal Botanic Gardens: Kew, UK, 2008.

11. Hajibabaei, K. Antioxidant properties of vitamin E. Ann. Res. Antioxid. 2016, 1, e22.

12. Shibula, K.; Velavan, S. Determination of phytocomponents in methanolic extract of Annona muricata leaf using GC-MS technique. Int. J. Pharmacogn. Phytochem. Res. 2015, 7, 1251-1255.

13. Salam, S.S.A.; Al Jaouni, S. Vitamin E ( $\alpha$-tocopherol) contents and antimutagenicity potentials Talbina (Hordeum vulgare L.). FEBS J. 2016, 283, 192.

14. Ajith, T.A.; Ann, M.; Thomas, J. Evaluation of comparative and combined antimutagenic potential of vitamin $\mathrm{C}$ and vitamin E using histidine mutant Salmonella typhimurium strains. Ind. J. Clin. Biochem. 2008, 23, 24-28. [CrossRef] [PubMed]

15. Negi, P.S.; Jayaprakasha, G.K.; Jena, B.S. Antioxidant and antimutagenic activities of pomegranate peel extracts. Food Chem. 2003, 80, 393-397. [CrossRef]

16. Dassprakash, M.V.; Arun, R.; Abraham, S.K.; Premkumar, K. In vitro and in vivo evaluation of antioxidant and antigenotoxic potential of leaf extract. Pharm. Biol. 2012, 50, 1523-1530. [CrossRef] [PubMed]

17. Pellati, F.; Bruni, R.; Righi, D.; Grandini, A.; Tognolini, M.; Pio Prencipe, F.; Poli, F.; Benvenuti, S.; Del Rio, D.; Rossi, D. Metabolite profiling of polyphenols in a Terminalia chebula Retzius ayurvedic decoction and evaluation of its chemopreventive activity. J. Ethnopharm. 2013, 147, 277-285. [CrossRef] [PubMed]

18. Zahin, M.; Ahmad, I.; Gupta, R.C.; Aqil, F. Punicalagin and ellagic acid demonstrate antimutagenic activity and inhibition of benzo[a]pyrene induced DNA adducts. Biomed. Res. Int. 2014, 2014, 467465. [CrossRef] [PubMed]

19. Okwu, D.E.; Ighodaro, B.U. GC-MS Evaluation of bioactive compounds and antibacterial activity of the oil fraction from the leaves of Alstonia boonei De Wild. Der Pharma Chemica 2010, 2, 261-272.

20. Devi, K.V.; Shanmugasundaram, R.; Mohan, V.R. GC-MS analysis of ethanol extract of Entada pursaetha DC seed. Biosci. Discov. 2012, 3, 30-33.

21. Rajeswari, G.; Murugan, M.; Mohan, V.R. GC-MS analysis of bioactive components of Hugonia mystax L. (Linaceae). Res. J. Pharm. Biol. Chem. Sci. 2012, 3, 301-308.

22. Lee, Y.S.; Kang, M.H.; Cho, Y.S.; Jeong, C.S. Effects of constituents of Amomum xanthioides on gastritis in rats and on growth of gastric cancer cells. Arch. Pharm. Res. 2007, 30, 436-443. [CrossRef] [PubMed]

23. Mishra, P.M.; Sree, A. Antibacterial activity and GCMS analysis of the extract of leaves of Finlaysonia obovata (a mangrove plant). Asian J. Plant. Sci. 2007, 6, 168-172. 
24. Hornby, J.M.; Jensen, E.C.; Lisec, A.D.; Tasto, J.J.; Jahnke, B.; Shoemaker, R.; Dussault, P.; Nickerson, K.W. Quorum sensing in the dimorphic fungus Candida albicans is mediated by farnesol. Appl. Environ. Microbiol. 2001, 67, 2982-2992. [CrossRef] [PubMed]

25. Wang, H.X.; Ng, T.B. Natural products with hypoglycemic, hypotensive, hypocholesterolemic, antiatherosclerotic and antithrombotic activities. Life Sci. 1999, 65, 2663-2677. [CrossRef]

26. Moon, D.O.; Kim, M.O.; Choi, Y.H.; Kim, G.Y. Beta-Sitosterol induces G2/M arrest, endoreduplication, and apoptosis through the Bcl-2 and PI3K/Akt signaling pathways. Cancer Lett. 2008, 264, 181-191. [CrossRef] [PubMed]

27. Sujatha, S.; Anand, S.; Sangeetha, K.N.; Shilpa, K.; Lakshmi, J.; Balakrishnan, A.; Lakshmi, B.S. Biological evaluation of (3ß)-STIGMAST-5-EN-3-OL as potent anti-diabetic agent in regulating glucose transport using in vitro model. Int. J. Diabetes Mellitus 2010, 2, 101-109. [CrossRef]

28. Nisar, M.; Ali, S.; Qaisar, M. Preliminary phytochemical screening of flowers, leaves, bark, stem and roots of Rhododendron arboreum. MEJSR 2011, 10, 472-476.

29. Mary, S.J.; Indira, S. Phytochemical and FT-IR spectral analysis of Rhododendron arboreum Sm. ssp. nilagiricum (Zenker) Tagg. Biosci. Discov. 2017, 8, 9-13.

30. Udgire, M.S.; Pathade, G.R. Evaluation of antimicrobial activities and phytochemical constituents of extracts of Valeriana wallichii. Asian J. Plant Sci. Res. 2013, 3, 55-59.

31. Jubie, S.; Dhanabal, S.P. Gas chromatography-mass spectrometry analysis and antibacterial activity of fatty acid mixture of Spirulina platensis. J. Pharm. Sci. Res. 2012, 4, 1836-1838.

32. Halliwell, B.; Gutteridge, J.M.C. The chemistry of free radicals and related reactive species. In Free Radicals in Biology and Medicine; Oxford University Press: Oxford, UK, 2007; pp. 60-61.

33. Marcocci, L.; Maguire, J.J.; Droylefaix, M.T.; Packer, L. The nitric oxide-scavenging properties of Ginkgo biloba extract EGb 761. Biochem. Biophys. Res. Commun. 1994, 201, 748-755. [CrossRef] [PubMed]

34. Halliwell, B.; Gutteridge, J.M.C.; Aruoma, O.I. The deoxyribose method: a simple "test-tube" assay for determination of rate constants for reaction of hydroxyl groups. Anal. Biochem. 1987, 165, 215-219. [CrossRef]

35. Aruoma, O.I.; Grootveld, M.; Halliwell, B. The role of iron in ascorbate dependent deoxyribose degradation. Evidence consistent with a site specific hydroxyl radical generation caused by iron ions bound to the deoxyribose molecule. J. Inorg. Biochem. 1987, 29, 289-299. [CrossRef]

36. Maron, D.H.; Ames, B.N. Revised methods for the Salmonella typhimurium mutagenicity test. Mut. Res. 1983, 113, 173-215. [CrossRef]

37. Bala, S.; Grover, I.S. Antimutagenicity of some citrus fruits. Mut. Res. 1989, 222, 141-148. [CrossRef]

38. Garner, R.C.; Miller, E.C.; Miller, J.A. Liver microsomal metabolism ofaflatoxin B1 to a reactive derivative toxic to Salmonella typhimurium TA1530. Cancer Res. 1972, 32, 2058-2066. [PubMed]

Sample Availability: Not available.

(C) 2018 by the authors. Licensee MDPI, Basel, Switzerland. This article is an open access article distributed under the terms and conditions of the Creative Commons Attribution (CC BY) license (http:// creativecommons.org/licenses/by/4.0/). 